\title{
What makes people believe that their party won the election?
}

\author{
Electoral Studies, accepted \\ (C) Electoral Studies
}

\begin{abstract}
This paper uses an original question to investigate voters' own evaluations of whether the party they voted for won or lost the election. We examine which aspect of the party's electoral performance has the strongest impact on voters' perceptions. The results reveal that supporters of the largest party - the party with most votes and seats in both Parliament and government almost unanimously believe that their party won the election. But we find that some supporters of smaller parties also feel their party won, when and if their party gained votes and seats compared to the previous election. Moreover, we test whether it is the party's performance at the district or national level that matters most. We find that voters' judgments are shaped mostly by electoral performance at the national level, but having the local candidate elected in the district can partially compensate for a national defeat.
\end{abstract}

Keywords: winner-loser gap; elections; voters; voting behaviour 
Free and fair elections constitute a basic ingredient of the democratic process. Much research has been devoted to examining the effect of participating in this democratic event on satisfaction with democracy and political trust. These studies have revealed that although democratic participation can increase these feelings of support for the system, it does not do so for all voters alike. More specifically, stark differences have been found between 'winners' and 'losers' (Anderson, Blais, Bowler, Donovan, \& Listhaug, 2005).

This literature investigates whether winners and losers differ in their attitudes towards the democratic system after an election (Blais \& Gélineau, 2007; Blais et al., 2017; Hooghe \& Stiers, 2016; Ferland, 2015; Singh et al., 2011). Time and again, research shows that electoral winners display significantly higher satisfaction with the democratic process (Anderson et al., 2005; Esaiasson, 2011). ${ }^{1}$ However, we do not know which aspects of party performance most strongly affect voters' perceptions of whether they won or lost the election. How do voters construe winning and losing? Do they see elections first and foremost as a contest for obtaining as many votes as possible, for getting as many representatives as possible in Parliament, or for maximising control of government?

Indeed, while some studies explicitly acknowledge that voters might understand winning and losing differently (Blais, Morin-Chassé, \& Singh, 2017; Hooghe \& Stiers, 2016; Singh, Karakoç, \& Blais, 2012), no research has related these measures to voters' own perceptions (for the single exception, see Singh et al., 2012). Usually, these studies assume that feelings of winning and losing are in line with how 'winning' is commonly perceived - i.e., being the 'first' or 'largest'. However, for some voters - especially supporters of small parties - 'winning' could mean that they obtain Parliamentary seats and hence have their voice heard in the political process or that they were able to send a signal through their votes. In this paper, we investigate what determines citizens' feelings of winning an election. We pay particular attention to what causes voters to deviate from the most common view of winning and losing - that is, why some voters feel like a winner even if their party did not become the largest party in the election.

Furthermore, it remains unclear whether voters distinguish the performance of their party at different levels. For instance, we do not know whether people attach more importance to winning in their own constituency or at the national level. The few studies that have looked at whether the electoral outcomes at the district level have a significant impact on voters' level

\footnotetext{
${ }^{1}$ Kostelka and Blais (2018) provide more insight in the casual direction of this effect. Using panel data, they demonstrate that turning out increases voters' level of satisfaction and not the reverse (i.e. people would turn out because they are more satisfied and not vice-versa).
} 
of satisfaction with democracy have come up with inconsistent findings (Anderson and Guillory, 1997; Blais and Gélineau, 2007; Henderson, 2008).

This paper fills these gaps in the literature by investigating what makes a voter feel she has won or lost the election, using data of the Making Electoral Democracy Work (MEDW) project. These data include an original question in which voters were asked whether they believe that the party they voted for had won or lost the election. We find that supporters of the largest party almost unequivocally feel that their party won the election, which is consistent with conventional wisdom. Then, we investigate the factors that cause voters to deviate from the commonly assumed definition of winning. Finally, we examine whether voters think they lost the election even if their preferred party was elected in their district, or whether this small electoral success can soften the effect of an electoral defeat at the national level.

\section{What makes people think that their party won or lost an election?}

The existence of a winner/loser-gap in attitudes towards the political system after an election is widely supported by previous research and has proven to be very robust (Anderson et al., 2005, Blais et al., 2017; Ferland, 2015; Singh et al., 2011). However, no study so far has examined voters' subjective assessments of electoral performance. This shows the lack of understanding of how voters themselves construe 'winning' or 'losing' an election. Do voters care most about their party being in government, or do they want first and foremost their views to be represented in the political debate - i.e., gaining votes so that their party is represented in Parliament? This distinction is grafted on a fundamental opposition between two contrasting views about democracy and elections (Thomassen, 2014, p. 2). While in majoritarian systems elections are mostly about selecting a government that represents the majority, in a consensus model of democracy the focus is on the election of a Parliament that is representative of the whole electorate (Lijphart, 2012; Powell 2000; Thomassen, 2014).

Most commonly, 'winning' means being 'first'. Hence, it is assumed that winning an election is mostly about being the largest party in terms of votes and seats in Parliament and government. ${ }^{2}$ This conception accords with the majoritarian view of elections. The assumption is, then, that voters construe winning as being the largest party:

\footnotetext{
${ }^{2}$ Note that, as will be explained below, we cannot distinguish being the 'largest party' from being 'in government'. However, in the one case under investigation where this is possible (Germany), we do distinguish dominant incumbent parties from junior coalition parties.".
} 
Hypothesis 1: Voters of the largest party are likely to feel that their party won the election.

However, voters of a small party may still feel they are winners if their party was 'successful' in some respects. First, in a consensual view of democracy, elections are held to assemble a Parliament in which the different opinions of voters are represented (Lijphart, 2012; Thomassen, 2014). Hence, supporters of small parties may attach importance to (gaining or losing) votes and hence representation in Parliament. Second, voters might vote for small parties to send a signal to the larger parties, and this signal becomes more effective if the party they turn to receives a substantial proportion of the votes (Kselman \& Niou, 2011). For these reasons, we expect that not all voters follow the most common understanding of 'winning', i.e. being the largest party. These considerations may be particularly relevant if and when voters view elections as a way to bring together different opinions and interests in society (Powell, 2000). Hence, we investigate whether voters attach importance to Parliamentary representation as well:

Hypothesis 2a: Voters of smaller parties that gained votes in the election are more likely to feel that their party won the election.

Hypothesis 2b: Voters of smaller parties that gained seats in the election are more likely to feel that their party won the election.

Our first goal in this study is to investigate which aspect of a party's electoral performance most strongly shapes voters' subjective evaluations of whether their party won or lost the election. Our data also allow us to go a step further, and to examine individual-level heterogeneity in voters' perceptions. More specifically, we identify two characteristics of voters that can be expected to influence their feelings of winning and losing.

First, voters who identify with a party are more optimistic with regard to the performance of the party (Stiers \& Dassonneville, 2018). On the other hand, partisanship has been argued to work as a 'perceptual screen', biasing perceptions of political facts (Campbell, Converse, Miller, and Stokes, 1960). Hence, partisan identifiers are likely to be less affected by a party's gains or losses in votes or seats, as their subjective perceptions might be biased upward. Both the direct effect of partisanship as well as its interaction with a party's electoral performance will be investigated. 
Hypothesis 3: While partisanship increases feelings of winning, party identification decreases the impact of a party's performance on voters' feelings of winning

Another individual-level factor is political information. Blais and Bodet (2006, p. 488) show that more informed voters are more prone to use 'objective' contextual information (e.g. polls, outcome of previous elections) when they are asked about their parties' chances of winning the election. Hence, we expect a stronger link between the electoral performance of a party and perceptions of winning among better-informed citizens.

Hypothesis 4: Political information increases the impact of a party's performance on voters'feelings of winning

\section{Electoral performance at the local and national level}

Another question that remains unanswered in the literature is whether electoral outcomes at the district level matter. Contradictory results have emerged in this regard. Using data from the United States, Anderson and LoTempio (2002) show that the electoral outcomes of 1972 and 1996 at the presidential (national) level affect citizens' level of satisfaction, but that the results at the congressional level do not. Henderson (2008) replicates this finding in parliamentary systems and demonstrates that the electoral results at the district level are not a significant predictor of satisfaction with democracy in Canada, the UK, and Australia. Contrarily, Blais and Gélineau (2007) show that during the 1997 Canadian election, performance at the district level had a significant positive impact on voters' satisfaction with democracy.

Given these conflicting findings, we have no clear expectation about whether the outcome at the district level does or does not matter in constructing voters' opinion about their status of winner or loser, and we hence do not formulate specific hypotheses. Previous studies already convincingly showed the impact of election results at the national level on voters' support for the democratic system. Using our original measure of voters' own perceptions, we are able to test in a more direct way whether or not voters also consider the local level as an additional factor when they come to the conclusion that the party they voted for won or lost the election. Finally, while previous studies were concerned with the effects of winning and losing on voters' satisfaction with democracy, we are dealing with how voters themselves define winning and losing. 


\section{Data and methods}

The data in this study come from the Making Electoral Democracy Work (MEDW) project (Blais, 2010; Stephenson et al., 2017). The project includes 27 electoral surveys in 5 different countries. The new question tapping individual perceptions of the winner or loser status of the party the voter voted for is available only for Canada, Spain, and Germany. Hence, we focus on these countries, for which we have 11 election studies conducted in the context of seven national or regional elections. The MEDW data are based on online quota-based surveys that guarantee the representativeness of the sample according to gender, age, education and region. For each election, there was a pre and a post-electoral panel survey. The control variables come from the pre-electoral survey. The question probing the dependent variable was included in the post-electoral survey. The exact wording of the question was "Would you say that the party you voted for:" and the answer choices were "won the election/lost the election/don't know".

\section{Methodology}

For each country, we first present a table describing voters' perceptions, together with an overview of the party's performance in the election. Following the hypotheses, we focus on the most commonly used indicators of winning and losing: being part of the government (coalition), gaining or losing votes, and gaining or losing seats. We pay special attention to the largest party in the election, as it is most commonly assumed that this party can be considered the winner of the election.

Second, we investigate which factors explain whether a voter thinks the party she voted for won or lost the election by estimating logistic regression models. As the first descriptive analyses clearly establish that a party's status as the largest party is the major determinant of voters' perceptions, we focus on the other factors that explain perceptions, apart from the party being the largest party or not. Therefore, in these models, first, we include a dummy variable 'largest party' that indicates whether a voter voted for the largest party or not. ${ }^{3}$

After including this dummy, we go on to test which other factors explain why voters feel the party they voted for won the election. To do so, we focus on measures that exemplify the different notions on the role of elections in a democracy. First, we include a dummy variable

\footnotetext{
${ }^{3}$ Note that in all the cases under investigation the party receiving the largest share of votes is also the party with most seats in both Parliament and government. There is therefore no ambiguity about who is the winner. However, this is not always the case, and in some contexts different parties could claim to be the winner.
} 
indicating whether the party the voter voted for was part of the government as a (junior) coalition partner. Second, to test for the consensual view, we include the percentage of vote and seat shares the party gained or lost compared to the previous election.

We finally test whether voters' characteristics explain perceptions of winning or losing the election. First, we test whether partisanship has a direct effect on voters' perceptions of winning or losing. In a second step, we include an interaction between partisanship and change in votes and change in seats respectively. Party identification is included as a dummy variable with value 1 if voters identify with a party and also voted for this party, and value 0 otherwise. ${ }^{4}$

Second, we test whether there is a stronger link between votes or seats gains or losses and perceptions among voters with higher levels of political information. Respondents were asked to associate pictures of political leaders and party slogans to the correct party. Each picture and slogan is coded 1 if the respondent associates it correctly with the party and 0 if not. ${ }^{5}$ This measure is rescaled from 0 to 1 . As political information is expected to affect the impact of a change in vote shares or seat shares on perceptions of winning and losing, it is included as an interaction in the models.

In the second part of the study, we use our unique measure to investigate whether feelings of winning and losing are primarily determined by performance in the national election or in the electoral district the voter lives in. In these analyses, we focus on the Canadian elections. ${ }^{6} \mathrm{We}$ compare the proportion of voters who feel they won the election in four different categories: (1) voters voting for the party that was elected in their district and formed the government; (2) voters voting for the party that is in the government but not for the candidate elected in their district; (3) voters voting for the party that was elected in their district but is in opposition at the national level; and (4) voters voting for the party that is not elected in their district and that is in the opposition at the national level.

\footnotetext{
${ }^{4}$ Voters might vote for another party than the one they identify with (for instance because they prefer the leader of another party or for strategic motivations). As perceptions of winning and losing were probed with regard to the party the voter voted for and partisan leanings should matter for the party with which voters identify, we only take into account voters who voted for the party with which they identify.

${ }^{5}$ All question wordings are available on www.electoraldemocracy.com.

${ }^{6}$ In Canada, voters cast a ballot at the district (or constituency) level, no matter if it is a regional or a national election. This is what we label as the 'local' level. The common practice is that the party with the most elected representatives will be called to form the government.
} 


\section{Results}

\section{$\underline{\text { Canada }}$}

We start with voters' perceptions of winning and losing in Canada. Table 1 summarises the performance of the parties with respect to the three aspects mentioned above: whether they entered or left government, and whether they gained or lost seats compared to the previous election. As we expect voters to understand 'winning' mostly as being the largest party in the election, that largest party is highlighted in bold. ${ }^{7}$

A first look at the proportion of voters feeling they won or lost the election indicates that it is mostly voting for the largest party that makes voters feel like winners: more than $90 \%$ of those who voted for the largest party believe that their party won the election. Furthermore, it needs to be noted that after the two regional elections, minority cabinets were formed - and this does not seem to matter for voters' perceptions of winning. Moreover, there do not seem to be strong differences between staying in government or entering government; voters of the largest party feel like their party won. For the smaller parties, the proportion of votes and seats seems to matter.

This first overview strongly suggests that perceptions of winning are mostly determined by being the largest party in the election. However, losing votes or seats may also influence whether or not a voter feels like the party she voted for won or lost the election. To get a more in-depth view, we estimate logistic regression models with perception of winning as the dependent variable. ${ }^{8}$ The results of these analyses are summarised in Table 2.

\footnotetext{
${ }^{7}$ As mentioned above, in all the elections included in our study, there is no ambiguity about which party is the largest, as the party with most votes is also the party with most seats in both Parliament and government.

${ }^{8}$ As we are interested in voters' perceptions of winning and losing, respondents using the 'don't know'-option $(12.25 \%$ of the total sample) were excluded from the analyses. However, additional tests distinguishing voters who felt the party they voted for won the election versus the other two categories (i.e., lost/don't know) lead to the same conclusions. Results of these multinominal logistic regressions are available upon request.
} 
Table 1. Perceptions of winning and losing in Canada

\begin{tabular}{|c|c|c|c|c|c|c|c|}
\hline $\begin{array}{l}\text { Election } \\
\text { survey }\end{array}$ & Party & $\begin{array}{c}\text { Government } \\
\text { status }\end{array}$ & $\begin{array}{l}\text { Vote share } \\
\text { status }\end{array}$ & $\begin{array}{l}\text { Seat share } \\
\text { status }\end{array}$ & $\begin{array}{c}\% \\
\text { won }\end{array}$ & $\%$ lost & $\begin{array}{c}\% \\
\text { don't } \\
\text { know }\end{array}$ \\
\hline \multirow{5}{*}{$\begin{array}{c}\text { Canada } \\
\text { National } \\
2015\end{array}$} & Liberal Party & $\begin{array}{l}\text { Entered } \\
\text { government }\end{array}$ & $\begin{array}{c}+20.6 \\
(39.5 \%)\end{array}$ & $\begin{array}{c}+44 \\
(54 \%)\end{array}$ & 98.3 & 1.3 & 0.4 \\
\hline & $\begin{array}{l}\text { New Democratic } \\
\text { Party }\end{array}$ & $\begin{array}{l}\text { Stayed in } \\
\text { opposition }\end{array}$ & $\begin{array}{c}-10.9 \\
(19.7 \%)\end{array}$ & $\begin{array}{c}-17 \\
(13 \%)\end{array}$ & 4.6 & 91.9 & 3.6 \\
\hline & Conservatives & $\begin{array}{l}\text { Left } \\
\text { government }\end{array}$ & $\begin{array}{c}-7.7 \\
(31.9 \%)\end{array}$ & $\begin{array}{c}-20 \\
(29 \%)\end{array}$ & 3.1 & 95.5 & 1.4 \\
\hline & Bloc Québécois & $\begin{array}{l}\text { Stayed in } \\
\text { opposition }\end{array}$ & $\begin{array}{c}-1.2 \\
(4.7 \%)\end{array}$ & $\begin{array}{c}+2 \\
(3 \%)\end{array}$ & 12.3 & 80.9 & 6.8 \\
\hline & Green Party & $\begin{array}{l}\text { Stayed in } \\
\text { opposition }\end{array}$ & $\begin{array}{c}-0.5 \\
(3.4 \%)\end{array}$ & $\begin{array}{c}0 \\
(0.3 \%)\end{array}$ & 3.0 & 88.5 & 8.5 \\
\hline \multirow{4}{*}{$\begin{array}{c}\text { Ontario } \\
\text { regional } \\
2011\end{array}$} & $\begin{array}{l}\text { Ontario Liberal } \\
\text { Party }\end{array}$ & $\begin{array}{l}\text { Stayed in } \\
\text { government }\end{array}$ & $\begin{array}{c}-4.7 \\
(37.7 \%)\end{array}$ & $\begin{array}{c}-17 \\
(50 \%)\end{array}$ & 96.7 & 1.5 & 1.8 \\
\hline & $\begin{array}{l}\text { Progressive } \\
\text { Conservative } \\
\text { Party }\end{array}$ & $\begin{array}{l}\text { Stayed in } \\
\text { opposition }\end{array}$ & $\begin{array}{c}+3.8 \\
(35.5 \%)\end{array}$ & $\begin{array}{c}+10 \\
(35 \%)\end{array}$ & 8.6 & 87.5 & 3.9 \\
\hline & $\begin{array}{l}\text { New Democratic } \\
\text { Party }\end{array}$ & $\begin{array}{l}\text { Stayed in } \\
\text { opposition }\end{array}$ & $\begin{array}{c}+5.9 \\
(22.7 \%)\end{array}$ & $\begin{array}{c}+7 \\
(16 \%)\end{array}$ & 19.5 & 63.6 & 13.9 \\
\hline & Green Party & $\begin{array}{l}\text { Stayed in } \\
\text { opposition }\end{array}$ & $\begin{array}{c}-5.1 \\
(2.9 \%)\end{array}$ & $\begin{array}{c}0 \\
(0 \%)\end{array}$ & 0.0 & 92.6 & 7.4 \\
\hline \multirow{6}{*}{$\begin{array}{l}\text { Quebec } \\
\text { regional } \\
2012\end{array}$} & Parti Québécois & $\begin{array}{l}\text { Entered } \\
\text { government }\end{array}$ & $\begin{array}{c}-3.2 \\
(32.0 \%)\end{array}$ & $\begin{array}{c}+3 \\
(50 \%)\end{array}$ & 93.4 & 3.8 & 2.8 \\
\hline & $\begin{array}{l}\text { Québec Liberal } \\
\text { Party }\end{array}$ & $\begin{array}{l}\text { Left } \\
\text { government }\end{array}$ & $\begin{array}{l}-10.9 \\
(31.2 \%)\end{array}$ & $\begin{array}{c}-13 \\
(40 \%)\end{array}$ & 25.6 & 69.6 & 4.8 \\
\hline & Québec Solidaire & $\begin{array}{l}\text { Stayed in } \\
\text { opposition }\end{array}$ & $\begin{array}{c}+2.3 \\
(6.0 \%)\end{array}$ & $\begin{array}{l}+0.1 \\
(2 \%)\end{array}$ & 51.8 & 35.7 & 12.5 \\
\hline & $\begin{array}{l}\text { Coalition avenir } \\
\text { Québec }\end{array}$ & $\begin{array}{l}\text { Stayed in } \\
\text { opposition }\end{array}$ & $\begin{array}{c}+10.7 \\
(27.1 \%)\end{array}$ & $\begin{array}{l}+10 \\
(15 \%)\end{array}$ & 19.7 & 69.4 & 11.0 \\
\hline & Option nationale & $\begin{array}{l}\text { Stayed in } \\
\text { opposition }\end{array}$ & $\begin{array}{c}+1.9 \\
(1.9 \%)\end{array}$ & $\begin{array}{c}0 \\
(0 \%)\end{array}$ & 0.0 & 91.7 & 8.3 \\
\hline & Green Party & $\begin{array}{l}\text { Stayed in } \\
\text { opposition }\end{array}$ & $\begin{array}{c}-1.2 \\
(1.0 \%)\end{array}$ & $\begin{array}{c}0 \\
(0 \%)\end{array}$ & 0.0 & 64.3 & 35.7 \\
\hline
\end{tabular}

Note: Government status indicates whether the party stayed in government, was in government but became an opposition party ('left government') or was an opposition party but entered government. Vote (seat) share status indicates the change in the vote (seat) share in percentage points. Numbers between brackets indicate the absolute vote (seat) share the party received in the election under investigation. \% won/lost/don't know represents the respondent's answers to our dependent variable. The party indicated in bold is the largest party in the electoral results - that will subsequently be included as 'largest party' in the regression analyses. 
Table 2. Logistic regression models predicting perceptions of winning in Canada

\begin{tabular}{|c|c|c|c|c|c|c|c|c|}
\hline & $\begin{array}{c}(1) \\
\text { B } \\
\text { (s.e.) }\end{array}$ & $\begin{array}{c}(2) \\
\text { B } \\
\text { (s.e.) }\end{array}$ & $\begin{array}{c}(3) \\
\text { B } \\
\text { (s.e.) }\end{array}$ & $\begin{array}{c}(4) \\
\text { B } \\
\text { (s.e.) }\end{array}$ & $\begin{array}{c}(5) \\
\text { B } \\
\text { (s.e.) }\end{array}$ & $\begin{array}{c}(6) \\
\text { B } \\
\text { (s.e.) }\end{array}$ & $\begin{array}{c}(7) \\
\text { B } \\
\text { (s.e.) }\end{array}$ & $\begin{array}{c}(8) \\
\text { B } \\
\text { (s.e.) } \\
\end{array}$ \\
\hline Largest party & $\begin{array}{c}6.866^{* * *} \\
(0.529)\end{array}$ & $\begin{array}{c}7.038^{* * * *} \\
(0.576)\end{array}$ & $\begin{array}{c}6.269^{* * *} \\
(0.327)\end{array}$ & $\begin{array}{c}6.269^{* * *} \\
(0.316)\end{array}$ & $\begin{array}{c}6.249^{* * * *} \\
(0.356)\end{array}$ & $\begin{array}{l}5.416^{* * *} \\
(1.038)\end{array}$ & $\begin{array}{l}6.258^{* * *} \\
(0.323)\end{array}$ & $\begin{array}{l}6.275^{* * *} \\
(0.313)\end{array}$ \\
\hline Change in vote share & & $\begin{array}{l}-0.007 \\
(0.014)\end{array}$ & & & & & & \\
\hline Change in seat share & & & $\begin{array}{c}0.013^{*} \\
(0.006)\end{array}$ & $\begin{array}{c}0.013^{*} \\
(0.006)\end{array}$ & $\begin{array}{c}0.013^{*} \\
(0.006)\end{array}$ & $\begin{array}{c}0.014^{*} \\
(0.006)\end{array}$ & $\begin{array}{c}0.014^{* * *} \\
(0.004)\end{array}$ & $\begin{array}{c}0.008 \\
(0.011)\end{array}$ \\
\hline Party ID & & & & $\begin{array}{c}0.362^{*} \\
(0.153)\end{array}$ & $\begin{array}{c}0.356^{*} \\
(0.152)\end{array}$ & $\begin{array}{c}0.366^{*} \\
(0.151)\end{array}$ & $\begin{array}{l}0.348^{* *} \\
(0.106)\end{array}$ & $\begin{array}{c}0.364^{*} \\
(0.148)\end{array}$ \\
\hline Information & & & & $\begin{array}{c}-0.221 \\
(0.325)\end{array}$ & $\begin{array}{c}-0.221 \\
(0.323)\end{array}$ & $\begin{array}{c}-0.399 \\
(0.394)\end{array}$ & $\begin{array}{c}-0.221 \\
(0.325)\end{array}$ & $\begin{array}{l}-0.156 \\
(0.360)\end{array}$ \\
\hline Largest party X party ID & & & & & $\begin{array}{c}0.064 \\
(0.491)\end{array}$ & & & \\
\hline Largest party $\mathrm{X}$ information & & & & & & $\begin{array}{c}1.387 \\
(1.587)\end{array}$ & & \\
\hline Change in seat share $X$ party ID & & & & & & & $\begin{array}{c}-0.002 \\
(0.005)\end{array}$ & \\
\hline Change in seat share $\mathrm{X}$ information & & & & & & & & $\begin{array}{c}0.009 \\
(0.025)\end{array}$ \\
\hline Constant & $\begin{array}{c}-0.799^{* * *} \\
(0.003)\end{array}$ & $\begin{array}{c}-0.792^{* * *} \\
(0.009)\end{array}$ & $\begin{array}{c}-0.540^{* * *} \\
(0.118)\end{array}$ & $\begin{array}{c}-0.547^{*} \\
(0.277)\end{array}$ & $\begin{array}{l}-0.545 \\
(0.289)\end{array}$ & $\begin{array}{l}-0.430 \\
(0.377)\end{array}$ & $\begin{array}{c}-0.543^{*} \\
(0.268)\end{array}$ & $\begin{array}{l}-0.589^{*} \\
(0.236)\end{array}$ \\
\hline$N$ & 4116 & 4116 & 4116 & 4116 & 4116 & 4116 & 4116 & 4116 \\
\hline pseudo $R^{2}$ & 0.715 & 0.715 & 0.716 & 0.718 & 0.718 & 0.718 & 0.718 & 0.718 \\
\hline Percentage correctly predicted & 93.95 & 93.95 & 93.95 & 93.95 & 93.95 & 93.95 & 93.95 & 93.95 \\
\hline Elections fixed effects included & Yes & Yes & Yes & Yes & Yes & Yes & Yes & Yes \\
\hline
\end{tabular}

Note: entries are results of logistic regression models explaining whether or not the voter thinks the party she voted for won the election. Election-dummies are included in the

models, but not reported for space considerations. Standard errors are clustered by election study. Significance levels: ${ }^{*}: \mathrm{p}<0.05 ;{ }^{* *}: \mathrm{p}<0.01 ;{ }^{* * *}: \mathrm{p}<0.001$. 
The results show, first of all, that having voted for the largest party has a very large positive impact on perceptions of winning and losing. More specifically, the probability of feeling like a winner increases from $8.8 \%$ to $98.4 \%$. The fact that this single variable has the strongest impact can also be seen at the model fit; including other variables increases the pseudo- $\mathrm{R}^{2}$ only marginally and leaves the percentage of correctly predicted observations unchanged. Hence, the first hypothesis is strongly supported by the results.

Investigating the other factors that explain perceptions of winning and losing, Models 2 and 3 indicate that the change in seat share has an impact on voters' perceptions, while a change in vote shares does not seem to have an effect. This lends support to hypothesis $2 \mathrm{~b}$. It needs to be noted, however, that the effect is small; gaining 5 percentage points in seats compared to remaining stable increases the probability of feeling like a winner by only 0.4 percentage points.

Turning to the individual-level variables, Model 4 provides support for the third hypothesis, as it shows that voters who identify with the party they voted are more likely to feel their party won the election - although the difference between partisans and non-partisans is small, with a change in predicted probability of feeling like a winner of 2 percentage points. To examine whether partisans use the objective information differently, it is interacted with the largest party dummy and change in seat shares. As can be seen in Table 2, the interactions are not significant. Hence, partisans do not seem to react differently to the government status or gains or losses in seats of their party.

Finally, we examine whether more informed voters are more strongly affected by electoral results by interacting the largest party dummy and change in seat shares with voters' level of political information. As the results in Model 6 and Model 8 show, there is no evidence of such interaction effects.

\section{$\underline{\text { Spain }}$}

Table 3 provides descriptive information for the Spanish elections. Perceptions of winning and losing in Spain also seem to be mainly determined by being the largest party in the election. Although the $\mathrm{CiU}$ - gaining 6 seats - is generally regarded to be a winner of the national elections, the results of the IU and UPYD show that voters largely feel their party lost the election if it does not enter the government - even if it gained votes and seats. 
Table 3. Perceptions of winning and losing in Spain

\begin{tabular}{|c|c|c|c|c|c|c|c|}
\hline Election & Party & Government status & $\begin{array}{c}\text { Vote share } \\
\text { status }\end{array}$ & $\begin{array}{c}\text { Seat } \\
\text { share } \\
\text { status }\end{array}$ & $\%$ won & $\%$ lost & $\begin{array}{c}\% \\
\text { don't } \\
\text { know }\end{array}$ \\
\hline \multirow{7}{*}{$\begin{array}{c}\text { Spain } \\
\text { national } \\
2011\end{array}$} & $\mathbf{P P}$ & $\begin{array}{l}\text { Entered } \\
\text { government }\end{array}$ & $\begin{array}{c}+4.5 \\
(44.6 \%)\end{array}$ & $\begin{array}{c}+9 \\
(53 \%)\end{array}$ & 99.8 & 0.0 & 0.3 \\
\hline & PSOE & Left government & $\begin{array}{c}-15.1 \\
(28.8 \%)\end{array}$ & $\begin{array}{c}-17 \\
(31 \%)\end{array}$ & 1.4 & 98.3 & 0.3 \\
\hline & $\mathrm{ICV} / \mathrm{IU}$ & $\begin{array}{l}\text { Stayed in } \\
\text { opposition }\end{array}$ & $\begin{array}{c}+3.0 \\
(6.9 \%)\end{array}$ & $\begin{array}{c}+3 \\
(3 \%)\end{array}$ & 33.8 & 43.8 & 22.5 \\
\hline & $\mathrm{CiU}$ & $\begin{array}{l}\text { Stayed in } \\
\text { opposition }\end{array}$ & $\begin{array}{c}+1.1 \\
(4.2 \%)\end{array}$ & $\begin{array}{c}+2 \\
(5 \%)\end{array}$ & 75.5 & 17.6 & 6.9 \\
\hline & ERC & $\begin{array}{l}\text { Stayed in } \\
\text { opposition }\end{array}$ & $\begin{array}{c}-0.1 \\
(1.1 \%)\end{array}$ & $\begin{array}{c}0 \\
(1 \%)\end{array}$ & 10.7 & 57.3 & 32.0 \\
\hline & UPYD & $\begin{array}{l}\text { Stayed in } \\
\text { opposition }\end{array}$ & $\begin{array}{c}+3.5 \\
(4.7 \%)\end{array}$ & $\begin{array}{c}+1 \\
(1 \%)\end{array}$ & 33.6 & 46.9 & 19.5 \\
\hline & $\begin{array}{l}\text { Plataforma } \\
\text { per } \\
\text { Catalunya }\end{array}$ & $\begin{array}{l}\text { Stayed in } \\
\text { opposition }\end{array}$ & $\begin{array}{c}+0.2 \\
(0.3 \%)\end{array}$ & $\begin{array}{c}0 \\
(0 \%)\end{array}$ & 7.4 & 81.5 & 11.1 \\
\hline
\end{tabular}

Note: Government status indicates whether the party remained part of the governing coalition ('stayed in government'), was in government but became an opposition party ('left government') or was an opposition party but entered the governing coalition ('entered government). Vote (seat) share status indicates the change in the vote (seat) share in percentage points. Numbers between brackets indicate the absolute vote (seat) share the party received in the election under investigation. \% won/lost/don't know represents the respondent's answers to our dependent variable. The party indicated in bold is the largest party in the electoral results - that will subsequently be included as 'largest party' in the regression analyses.

To get a more in-depth view on the factors explaining voters' perceptions, we estimate logistic regression models - the results of which are summarised in Table 4. Note that we do not include our dummy for 'largest party'. As can be seen in Table 3, all those who voted for the Partido Popular indicate that their party won the election (apart from one 'don't know' answer). Thus, a dummy indicating a vote for this party has a perfect fit with the dependent variable, and it cannot be included in the analyses. Therefore, in these analyses, we do not include the 'largest party' dummy, and as there is no variance in their answers to explain, we exclude the voters of the Partido Popular. Table 3 already indicated that government status has a very large positive impact, and the results in Table 4 show the factors explaining the perceptions of the voters of the other parties. 
Table 4. Logistic regression models predicting perceptions of winning in Spain

\begin{tabular}{|c|c|c|c|c|c|c|c|c|}
\hline & $\begin{array}{c}(1) \\
\text { B } \\
\text { (s.e.) }\end{array}$ & $\begin{array}{c}(2) \\
\text { B } \\
\text { (s.e.) }\end{array}$ & $\begin{array}{c}(3) \\
\text { B } \\
\text { (s.e.) }\end{array}$ & $\begin{array}{c}(4) \\
\text { B } \\
\text { (s.e.) }\end{array}$ & $\begin{array}{c}\text { (5) } \\
\text { B } \\
\text { (s.e.) }\end{array}$ & $\begin{array}{c}\text { (6) } \\
\text { B } \\
\text { (s.e.) }\end{array}$ & $\begin{array}{c}\text { (7) } \\
\text { B } \\
\text { (s.e.) }\end{array}$ & $\begin{array}{c}(8) \\
\text { B } \\
\text { (s.e.) }\end{array}$ \\
\hline Change in vote share & $\begin{array}{l}0.221^{* * *} \\
(0.002)\end{array}$ & & $\begin{array}{c}0.217^{* * *} \\
(0.004)\end{array}$ & & $\begin{array}{c}0.184^{* * *} \\
(0.008)\end{array}$ & $\begin{array}{c}0.028^{* * *} \\
(0.007)\end{array}$ & & \\
\hline Change in seat share & & $\begin{array}{c}0.265^{* * *} \\
(0.000)\end{array}$ & & $\begin{array}{c}0.267^{* * *} \\
(0.004)\end{array}$ & & & $\begin{array}{c}0.233^{* * *} \\
(0.010)\end{array}$ & $\begin{array}{c}-0.112^{* * *} \\
(0.016)\end{array}$ \\
\hline Party ID & & & $\begin{array}{c}-0.266 \\
(0.590)\end{array}$ & $\begin{array}{c}0.019 \\
(0.479)\end{array}$ & $\begin{array}{c}-1.051 \\
(0.628)\end{array}$ & $\begin{array}{c}-0.277 \\
(0.608)\end{array}$ & $\begin{array}{l}-0.206 \\
(0.522)\end{array}$ & $\begin{array}{l}-0.046 \\
(0.547)\end{array}$ \\
\hline information & & & $\begin{array}{c}0.485 \\
(0.583)\end{array}$ & $\begin{array}{c}0.713 \\
(0.433)\end{array}$ & $\begin{array}{c}0.501 \\
(0.554)\end{array}$ & $\begin{array}{c}0.216 \\
(0.741)\end{array}$ & $\begin{array}{c}0.708 \\
(0.441)\end{array}$ & $\begin{array}{l}-0.047 \\
(0.317)\end{array}$ \\
\hline Change in vote share $X$ party ID & & & & & $\begin{array}{l}0.351^{* * * *} \\
(0.033)\end{array}$ & & & \\
\hline Change in vote share $\mathrm{X}$ information & & & & & & $\begin{array}{c}0.276^{* * *} \\
(0.003)\end{array}$ & & \\
\hline Change in seat share $X$ party ID & & & & & & & $\begin{array}{c}0.180^{* * * *} \\
(0.005)\end{array}$ & \\
\hline Change in seat share $\mathrm{X}$ information & & & & & & & & $\begin{array}{c}0.676^{* * *} \\
(0.046)\end{array}$ \\
\hline Constant & $\begin{array}{c}-0.298 \\
(0.402) \\
\end{array}$ & $\begin{array}{c}-0.228 \\
(0.223) \\
\end{array}$ & $\begin{array}{c}-0.622^{* * *} \\
(0.047) \\
\end{array}$ & $\begin{array}{c}-0.759^{* * * *} \\
(0.008) \\
\end{array}$ & $\begin{array}{c}-0.601^{* * * *} \\
(0.033) \\
\end{array}$ & $\begin{array}{c}-0.462^{* * *} \\
(0.042) \\
\end{array}$ & $\begin{array}{c}-0.715^{* * *} \\
(0.029) \\
\end{array}$ & $\begin{array}{c}-0.373^{* * * *} \\
(0.026) \\
\end{array}$ \\
\hline$N$ & 639 & 639 & 639 & 639 & 639 & 639 & 639 & 639 \\
\hline pseudo $R^{2}$ & 0.281 & 0.321 & 0.283 & 0.323 & 0.292 & 0.290 & 0.326 & 0.341 \\
\hline Percentage correctly predicted & 62.44 & 77.15 & 70.42 & 78.25 & 70.42 & 69.95 & 78.09 & 77.93 \\
\hline Elections fixed effects included & Yes & Yes & Yes & Yes & Yes & Yes & Yes & Yes \\
\hline
\end{tabular}


As can be seen in Table 4, both the change in vote share as well as the change in seat share significantly predict voters' perceptions of winning and losing, and these effects hold including the individual-level control variables. ${ }^{9}$ In terms of substantive effect sizes, increasing the vote share by 5 percentage points increases the probability of feeling like a winner from $43 \%$ to $69 \%$ compared to receiving the same share of the votes. Likewise, going from a stable seat share to gaining 5 points increases the likelihood of feeling like a winner by 31 percentagepoints. Furthermore, while the results in Model 3 and Model 4 show that partisanship does not have an effect on voters' perceptions, the interaction effects show surprising results: while the interaction between information and the parties' performances are significantly positive as expected, the interactions between party identification and the party performance are significantly positive as well. Hence, contrary to our third hypothesis, in Spain voters who identify with the party they voted for seem to react more strongly to the objective performance of their party. More specifically, while the marginal effect of vote-change (seat-change) amounts to 3(4) points for non-partisans, it amounts to 7(6) points for partisans.

\section{Germany}

Finally, we conduct the same tests in Germany. First, the proportions of the voters' perceptions are summarised by party in Table 5. The results seem to be largely in line with those of Canada and Spain. The single most influential factor for feelings of winning and losing is whether or not the party the voter voted for is the largest party in the election. Furthermore, also in Germany there do not seem to be strong differences between staying in government or entering government - as long as the party has the largest share of votes and seats. An interesting pattern emerges for the SPD in the national election; although it entered the governing collation with CDU, most of its voters believe it lost the election. In Germany, perceptions of winning and losing are strongly determined by whether or not the party delivers the Chancellor. In this case, although the SPD entered a coalition with CDU, it was the CDU who delivered the Chancellor, and as a consequence SPD voters were prone to conclude that their party lost the election.

\footnotetext{
${ }^{9}$ Note that we do not include both measures in one model, as this results in problems of multicollinearity.
} 
Table 5. Perceptions of winning and losing in Germany

\begin{tabular}{|c|c|c|c|c|c|c|c|}
\hline $\begin{array}{l}\text { Election } \\
\text { survey }\end{array}$ & Party & $\begin{array}{l}\text { Government } \\
\text { status }\end{array}$ & $\begin{array}{c}\text { Vote share } \\
\text { status }\end{array}$ & $\begin{array}{c}\text { Seat share } \\
\text { status }\end{array}$ & $\%$ won & $\%$ lost & $\begin{array}{l}\% \text { don't } \\
\text { know }\end{array}$ \\
\hline \multirow{8}{*}{$\begin{array}{c}\text { Germany } \\
\text { national } \\
2013\end{array}$} & CDU & $\begin{array}{l}\text { Stayed in } \\
\text { government }\end{array}$ & $\begin{array}{c}+6.9 \\
(34.1 \%)\end{array}$ & $\begin{array}{c}+7 \\
(40 \%)\end{array}$ & 96.2 & 1.8 & 2.0 \\
\hline & SPD & $\begin{array}{l}\text { Entered } \\
\text { government }\end{array}$ & $\begin{array}{c}+2.7 \\
(25.7 \%)\end{array}$ & $\begin{array}{c}+7 \\
(31 \%)\end{array}$ & 36.2 & 43.9 & 19.9 \\
\hline & Greens & $\begin{array}{l}\text { Stayed in } \\
\text { opposition }\end{array}$ & $\begin{array}{c}-2.3 \\
(8.4 \%)\end{array}$ & $\begin{array}{c}-1 \\
(10 \%)\end{array}$ & 7.0 & 84.3 & 8.7 \\
\hline & FDP & $\begin{array}{l}\text { Left } \\
\text { government }\end{array}$ & $\begin{array}{c}-9.8 \\
(4.8 \%)\end{array}$ & $\begin{array}{l}-15 \\
(0 \%)\end{array}$ & 4.8 & 85.7 & 9.5 \\
\hline & Left & $\begin{array}{l}\text { Stayed in } \\
\text { opposition }\end{array}$ & $\begin{array}{c}-3.3 \\
(8.6 \%)\end{array}$ & $\begin{array}{c}-2 \\
(10 \%)\end{array}$ & 50.2 & 28.3 & 21.5 \\
\hline & Pirates & $\begin{array}{l}\text { Stayed in } \\
\text { opposition }\end{array}$ & $\begin{array}{c}+0.2 \\
(2.2 \%)\end{array}$ & $\begin{array}{c}0 \\
(0 \%)\end{array}$ & 9.4 & 58.9 & 31.8 \\
\hline & AFD & $\begin{array}{l}\text { Stayed in } \\
\text { opposition }\end{array}$ & $\begin{array}{c}+4.7 \\
(4.7 \%)\end{array}$ & $\begin{array}{c}0 \\
(0 \%)\end{array}$ & 72.2 & 14.1 & 13.7 \\
\hline & $\begin{array}{l}\text { Free } \\
\text { Voters }\end{array}$ & $\begin{array}{l}\text { Stayed in } \\
\text { opposition }\end{array}$ & $\begin{array}{c}+1.0 \\
(1.0 \%)\end{array}$ & $\begin{array}{c}0 \\
(0 \%)\end{array}$ & 7.5 & 78.3 & 14.2 \\
\hline \multirow{6}{*}{$\begin{array}{l}\text { Lower } \\
\text { Saxony } \\
\text { regional } \\
2013\end{array}$} & SPD & $\begin{array}{l}\text { Entered } \\
\text { government }\end{array}$ & $\begin{array}{c}+2.3 \\
(32.6 \%)\end{array}$ & $\begin{array}{c}+1 \\
(36 \%)\end{array}$ & 92.8 & 2.6 & 4.7 \\
\hline & $\mathrm{CDU}$ & $\begin{array}{l}\text { Left } \\
\text { government }\end{array}$ & $\begin{array}{c}-6.5 \\
(36.0 \%)\end{array}$ & $\begin{array}{c}-10 \\
(39 \%)\end{array}$ & 20.0 & 70.8 & 10.2 \\
\hline & Greens & $\begin{array}{l}\text { Entered } \\
\text { government }\end{array}$ & $\begin{array}{c}+5.7 \\
(13.7 \%)\end{array}$ & $\begin{array}{c}+6 \\
(15 \%)\end{array}$ & 94.4 & 1.4 & 4.2 \\
\hline & FDP & $\begin{array}{l}\text { Stayed in } \\
\text { opposition }\end{array}$ & $\begin{array}{c}+1.7 \\
(9.9 \%)\end{array}$ & $\begin{array}{c}+1 \\
(10 \%)\end{array}$ & 84.3 & 9.8 & 5.9 \\
\hline & Left & $\begin{array}{l}\text { Stayed in } \\
\text { opposition }\end{array}$ & $\begin{array}{l}-4.0 \\
(3.1 \%)\end{array}$ & $\begin{array}{l}-8 \\
(0 \%)\end{array}$ & 2.9 & 82.4 & 14.7 \\
\hline & Pirates & $\begin{array}{l}\text { Stayed in } \\
\text { opposition }\end{array}$ & $\begin{array}{c}+0.2 \\
(2.1 \%)\end{array}$ & $\begin{array}{c}0 \\
(0 \%)\end{array}$ & 13.3 & 66.7 & 20.0 \\
\hline \multirow{7}{*}{$\begin{array}{c}\text { Bavaria } \\
\text { regional } \\
2013\end{array}$} & CSU & $\begin{array}{l}\text { Stayed in } \\
\text { government }\end{array}$ & $\begin{array}{c}+4.3 \\
(47.7 \%)\end{array}$ & $\begin{array}{c}+5 \\
(56 \%)\end{array}$ & 92.0 & 2.2 & 5.8 \\
\hline & SPD & $\begin{array}{l}\text { Stayed in } \\
\text { opposition }\end{array}$ & $\begin{array}{c}+2.0 \\
(20.6 \%)\end{array}$ & $\begin{array}{c}+2 \\
(23 \%)\end{array}$ & 34.4 & 41.9 & 23.7 \\
\hline & Greens & $\begin{array}{l}\text { Stayed in } \\
\text { opposition }\end{array}$ & $\begin{array}{c}-0.8 \\
(8.6 \%)\end{array}$ & $\begin{array}{c}-1 \\
(10 \%)\end{array}$ & 9.2 & 66.1 & 24.7 \\
\hline & $\begin{array}{l}\text { Free } \\
\text { Voters }\end{array}$ & $\begin{array}{l}\text { Stayed in } \\
\text { opposition }\end{array}$ & $\begin{array}{c}-1.2 \\
(9.0 \%)\end{array}$ & $\begin{array}{c}-1 \\
(11 \%)\end{array}$ & 28.7 & 37.5 & 33.8 \\
\hline & FDP & $\begin{array}{l}\text { Left } \\
\text { government }\end{array}$ & $\begin{array}{c}-4.7 \\
(3.3 \%)\end{array}$ & $\begin{array}{l}-19 \\
(0 \%)\end{array}$ & 1.4 & 93.0 & 5.6 \\
\hline & Left & $\begin{array}{l}\text { Stayed in } \\
\text { opposition }\end{array}$ & $\begin{array}{l}-2.2 \\
(2.1 \%)\end{array}$ & $\begin{array}{c}0 \\
(0 \%)\end{array}$ & 3.5 & 69.0 & 27.6 \\
\hline & Pirates & $\begin{array}{l}\text { Stayed in } \\
\text { opposition }\end{array}$ & $\begin{array}{c}+2.0 \\
(2.0 \%)\end{array}$ & $\begin{array}{c}0 \\
(0 \%)\end{array}$ & 13.2 & 47.2 & 39.6 \\
\hline
\end{tabular}

Note: Government status indicates whether the party remained part of the governing coalition ('stayed in government'), was in government but became an opposition party ('left government') or was an opposition party but entered the governing coalition ('entered government). Vote (seat) share status indicates the change in the vote (seat) share in percentage points. Numbers between brackets indicate the absolute vote (seat) share the party received in the election under investigation. \% won/lost/don't know represents the respondent's answers to our dependent variable. The party indicated in bold is the largest party in the electoral results - that will subsequently be included as 'largest party' in the regression analyses. 
The results of the German case also allow to examine parties that are running for the first time. In the case of the AFD in the national elections, the results indicate that a majority of the voters think their party won the election - despite the fact that it was 0.3 percentage point short of reaching the electoral threshold. The case of the Pirate Party in Bavaria, however, shows a different picture: here, voters seem to have difficulties in rating their party's performance, as almost $40 \%$ of the voters do not know whether their party won the election.

To investigate the general patterns, also for the German case, we estimate logistic logit models, the results of which are summarised in Table 6 . 
Table 6. Logistic regression models predicting perceptions of winning in Germany

\begin{tabular}{|c|c|c|c|c|c|c|c|c|c|c|c|}
\hline & $\begin{array}{c}(1) \\
\text { B } \\
\text { (s.e.) }\end{array}$ & $\begin{array}{c}(2) \\
\text { B } \\
\text { (s.e.) }\end{array}$ & $\begin{array}{c}(3) \\
\text { B } \\
\text { (s.e.) }\end{array}$ & $\begin{array}{c}(4) \\
\text { B } \\
\text { (s.e.) }\end{array}$ & $\begin{array}{c}(5) \\
\text { B } \\
\text { (s.e.) }\end{array}$ & $\begin{array}{c}(6) \\
\text { B } \\
\text { (s.e.) }\end{array}$ & $\begin{array}{c}(7) \\
\text { B } \\
\text { (s.e.) }\end{array}$ & $\begin{array}{c}(8) \\
\text { B } \\
\text { (s.e.) }\end{array}$ & $\begin{array}{c}(9) \\
\text { B } \\
\text { (s.e.) }\end{array}$ & $\begin{array}{c}(10) \\
\text { B } \\
\text { (s.e.) }\end{array}$ & $\begin{array}{c}(11) \\
\text { B } \\
\text { (s.e.) }\end{array}$ \\
\hline Largest party & $\begin{array}{l}4.431^{* * * *} \\
(0.147)\end{array}$ & $\begin{array}{l}4.829^{* * *} \\
(0.407)\end{array}$ & $\begin{array}{l}3.181^{* * *} \\
(0.439)\end{array}$ & $\begin{array}{l}3.953^{* * *} \\
(0.273)\end{array}$ & $\begin{array}{l}3.138^{* * *} \\
(0.540)\end{array}$ & $\begin{array}{l}2.786^{* * *} \\
(0.594)\end{array}$ & $\begin{array}{l}2.869^{* * *} \\
(0.691)\end{array}$ & $\begin{array}{l}3.134^{* * *} \\
(0.548)\end{array}$ & $\begin{array}{l}3.154^{* * *} \\
(0.525)\end{array}$ & $\begin{array}{c}2.954^{* * *} \\
(0.432)\end{array}$ & $\begin{array}{l}3.187^{* * *} \\
(0.521)\end{array}$ \\
\hline Junior cabinet party & & $\begin{array}{l}1.349^{* *} \\
(0.511)\end{array}$ & & & $\begin{array}{l}-0.059 \\
(0.385)\end{array}$ & $\begin{array}{l}-0.063 \\
(0.394)\end{array}$ & $\begin{array}{l}-0.050 \\
(0.395)\end{array}$ & $\begin{array}{l}-0.019 \\
(0.166)\end{array}$ & $\begin{array}{c}0.261 \\
(0.606)\end{array}$ & $\begin{array}{l}-0.238 \\
(0.440)\end{array}$ & $\begin{array}{l}-0.042 \\
(0.397)\end{array}$ \\
\hline $\begin{array}{l}\text { Change in vote } \\
\text { share }\end{array}$ & & & $\begin{array}{l}0.233^{*} \\
(0.094)\end{array}$ & & $\begin{array}{c}0.237^{*} \\
(0.110)\end{array}$ & $\begin{array}{c}0.239^{*} \\
(0.110)\end{array}$ & $\begin{array}{l}0.236^{*} \\
(0.110)\end{array}$ & $\begin{array}{c}0.237^{*} \\
(0.108)\end{array}$ & $\begin{array}{l}0.234^{*} \\
(0.107)\end{array}$ & $\begin{array}{c}0.195 \\
(0.102)\end{array}$ & $\begin{array}{l}0.300^{* *} \\
(0.113)\end{array}$ \\
\hline $\begin{array}{l}\text { Change in seat } \\
\text { share }\end{array}$ & & & & $\begin{array}{c}0.065 \\
(0.044)\end{array}$ & & & & & & & \\
\hline Party ID & & & & & $\begin{array}{c}0.080 \\
(0.344)\end{array}$ & $\begin{array}{c}0.010 \\
(0.336)\end{array}$ & $\begin{array}{c}0.079 \\
(0.344)\end{array}$ & $\begin{array}{c}0.103 \\
(0.418)\end{array}$ & $\begin{array}{c}0.085 \\
(0.335)\end{array}$ & $\begin{array}{l}-0.083 \\
(0.322)\end{array}$ & $\begin{array}{c}0.094 \\
(0.321)\end{array}$ \\
\hline Information & & & & & $\begin{array}{c}0.085 \\
(0.194)\end{array}$ & $\begin{array}{c}0.085 \\
(0.196)\end{array}$ & $\begin{array}{c}0.039 \\
(0.166)\end{array}$ & $\begin{array}{c}0.084 \\
(0.201)\end{array}$ & $\begin{array}{c}0.196 \\
(0.348)\end{array}$ & $\begin{array}{c}0.083 \\
(0.185)\end{array}$ & $\begin{array}{c}0.177 \\
(0.256)\end{array}$ \\
\hline $\begin{array}{l}\text { Largest party X } \\
\text { party ID }\end{array}$ & & & & & & $\begin{array}{c}0.728 \\
(0.406)\end{array}$ & & & & & \\
\hline $\begin{array}{l}\text { Largest Party X } \\
\text { information }\end{array}$ & & & & & & & $\begin{array}{c}0.467 \\
(0.691)\end{array}$ & & & & \\
\hline $\begin{array}{l}\text { Junior cabinet party } \\
\text { X party ID }\end{array}$ & & & & & & & & $\begin{array}{l}-0.080 \\
(0.436)\end{array}$ & & & \\
\hline $\begin{array}{l}\text { Junior cabinet party } \\
\mathrm{X} \text { information }\end{array}$ & & & & & & & & & $\begin{array}{l}-0.491 \\
(0.953)\end{array}$ & & \\
\hline $\begin{array}{l}\text { Change in vote } \\
\text { share X party ID }\end{array}$ & & & & & & & & & & $\begin{array}{c}0.185 \\
(0.112)\end{array}$ & \\
\hline $\begin{array}{l}\text { Change in vote } \\
\text { share } X \text { information }\end{array}$ & & & & & & & & & & & $\begin{array}{l}-0.117 \\
(0.155)\end{array}$ \\
\hline Constant & $\begin{array}{c}-0.794^{* * *} \\
(0.015)\end{array}$ & $\begin{array}{c}-0.829^{* * *} \\
(0.030)\end{array}$ & $\begin{array}{c}-0.772^{* * *} \\
(0.033)\end{array}$ & $\begin{array}{c}-0.789^{* * *} \\
(0.018)\end{array}$ & $\begin{array}{c}-0.853^{* * *} \\
(0.065)\end{array}$ & $\begin{array}{c}-0.833^{* * *} \\
(0.068)\end{array}$ & $\begin{array}{l}-0.824^{* * *} \\
(0.094)\end{array}$ & $\begin{array}{c}-0.860^{* * *} \\
(0.072)\end{array}$ & $\begin{array}{c}-0.922^{* * *} \\
(0.079)\end{array}$ & $\begin{array}{c}-0.840^{* * * *} \\
(0.040)\end{array}$ & $\begin{array}{c}-0.916^{* * *} \\
(0.037)\end{array}$ \\
\hline $\begin{array}{l}N \\
\text { pseudo } R^{2}\end{array}$ & $\begin{array}{l}5087 \\
0.401\end{array}$ & $\begin{array}{l}5087 \\
0.426\end{array}$ & $\begin{array}{l}5087 \\
0.454\end{array}$ & $\begin{array}{l}5087 \\
0.432\end{array}$ & $\begin{array}{l}5087 \\
0.454\end{array}$ & $\begin{array}{l}5087 \\
0.455\end{array}$ & $\begin{array}{l}5087 \\
0.454\end{array}$ & $\begin{array}{l}5087 \\
0.454\end{array}$ & $\begin{array}{l}5087 \\
0.454\end{array}$ & $\begin{array}{l}5087 \\
0.460\end{array}$ & $\begin{array}{l}5087 \\
0.455\end{array}$ \\
\hline $\begin{array}{l}\text { Percentage } \\
\text { correctly predicted }\end{array}$ & 81.27 & 81.48 & 83.13 & 80.81 & 83.13 & 83.13 & 83.13 & 83.13 & 82.80 & 82.80 & 83.00 \\
\hline $\begin{array}{l}\text { Elections fixed } \\
\text { effects included }\end{array}$ & Yes & Yes & Yes & Yes & Yes & Yes & Yes & Yes & Yes & Yes & Yes \\
\hline
\end{tabular}

Note: entries are results of logistic regression models explaining whether or not the voter thinks the party she voted for won the election. Election-dummies are included in the models, but not reported for space considerations. Standard errors are clustered by election study. Significance levels: ${ }^{*}: \mathrm{p}<0.05 ;{ }^{* *}: \mathrm{p}<0.01 ;{ }^{* * *}: \mathrm{p}<0.001$. 
In line with the findings in Canada and Spain, the results show that voters of the largest party feel that the party won the election to a very large extent - with the probability of feeling like a winner increasing from $35 \%$ to $98 \%$. However, the result in Model 2 shows that also voters of smaller parties that make part of the governing coalition believe that their party won the election - this result is most likely driven by the high proportion of Green voters in the Lower Saxony elections that think their party won. Furthermore, the results seem to suggest that next to being the largest party in Germany, it is a change in vote share that influences voters' perceptions of winning and losing, rather than a change in seat share - and this effect remains controlling for junior government party status, while the effect of this latter indicator is rendered non-significant when we control for change in vote shares. Furthermore, contrary to the results in Canada, the effect of the change in vote share is substantial - with an increase in probability of feeling like a winner of 17 percentage points when the party gained 5 percentage points in votes compared to a stable vote share. Turning to the individual-level controls, the results seem to indicate that there are no effects of either partisan leanings or political information - neither direct, nor in interaction with the main variables of interest.

\section{Electoral performance in the district versus nationally}

To test whether voters focus entirely on the outcome of the national election, or whether they also respond to the party's performance in their own electoral district - and whether a good performance at one level can compensate a poor result at the other level - we investigate the proportion of voters who feel they won or lost the election in Canadian elections, based on the performance of their party in their district(i.e., the party they voted for had its candidate elected in the district), and at the national level (i.e., the party they voted is in government). The results are summarised in Table 7. 
Table 7. Feelings of winning in four groups of voters in Canada

\begin{tabular}{lcccc}
\hline Party Performance & $\begin{array}{c}\text { Elected } \\
\text { nationally and } \\
\text { in district } \\
(\%)\end{array}$ & $\begin{array}{c}\text { Elected } \\
\text { nationally, not } \\
\text { in district } \\
(\%)\end{array}$ & $\begin{array}{c}\text { Not elected } \\
\text { nationally, } \\
\text { elected in } \\
\text { district } \\
(\%)\end{array}$ & $\begin{array}{c}\text { Not elected } \\
\text { nationally } \\
\text { nor in district } \\
(\%)\end{array}$ \\
\hline National 2015 & 99.1 & 98.0 & 11.3 & 2.6 \\
Québec 2012 & 94.6 & 97.2 & 33.6 & 24.0 \\
Ontario 2011 & 99.4 & 97.8 & 22.4 & 6.3 \\
\hline
\end{tabular}

Note: entries denote the percentages of respondents feeling like the party they voted for won the election.

The results in Table 7 show that voters whose party performed well at both levels almost unanimously think their party won the election. Also, those whose party is elected nationally but whose candidate in their district was not elected also overwhelmingly believe that their party won. Voters whose party performed poorly at both levels convincingly state that they lost the election. However, the main interest is in the difference between this latter group (i.e., the last column in Table 7) and the group of voters whose party is in opposition at the national/regional level, but whose candidate was elected in their district (i.e., the second to last column of Table 7). Comparing the proportions of voters who feel like they won the election between these columns, it seems that a good outcome in the district softens the blow of a bad result at the national level. In each election under investigation, there is a substantial minority of voters feeling that their party won the election when that party had its candidate elected in the district compared to the voters losing at both levels.

To investigate this finding in-depth, we estimate logistic regression models with feelings of winning as dependent variable, and we include the different groups of voters defined in Table 7 in the analysis. As we are mostly interested in the difference between those voters whose preferred party did not get elected at any level versus those voters whose party was elected in their districtbut not at the national level, we include the former category as reference category. The results are summarised in Table $8 .{ }^{10}$

\footnotetext{
${ }^{10} \mathrm{We}$ also estimated the interactions between the different groups of voters on the one hand and partisanship and information on the other hand. These analyses did not reveal substantial differences between the groups for partisans or voters with different levels of knowledge - although it needs to be noted that the models suffered from low numbers of observations. The results are available upon request.
} 
Table 8. Logistic regression models predicting feelings of winning and losing for different groups of voters in Canada

\begin{tabular}{|c|c|c|c|c|c|c|}
\hline & \multicolumn{2}{|c|}{ Canada 2015} & \multicolumn{2}{|c|}{ Québec 2012} & \multicolumn{2}{|c|}{ Ontario 2011} \\
\hline & $\begin{array}{c}\text { Model } 1 \\
\text { B } \\
\text { (s.e.) }\end{array}$ & $\begin{array}{c}\text { Model } 2 \\
\text { B } \\
\text { (s.e.) }\end{array}$ & $\begin{array}{c}\text { Model } 1 \\
\text { B } \\
\text { (s.e.) }\end{array}$ & $\begin{array}{c}\text { Model } 2 \\
\text { B } \\
\text { (s.e.) }\end{array}$ & $\begin{array}{c}\text { Model } 1 \\
\text { B } \\
\text { (s.e.) }\end{array}$ & $\begin{array}{c}\text { Model } 2 \\
\text { B } \\
\text { (s.e.) }\end{array}$ \\
\hline \multicolumn{7}{|l|}{ Not elected any level (ref.) } \\
\hline Only elected in district & $\begin{array}{l}1.485^{* * *} \\
(0.215)\end{array}$ & $\begin{array}{l}1.485^{* * * *} \\
(0.216)\end{array}$ & $\begin{array}{l}0.499^{*} \\
(0.246)\end{array}$ & $\begin{array}{c}0.545^{*} \\
(0.250)\end{array}$ & $\begin{array}{l}1.477^{* * * *} \\
(0.351)\end{array}$ & $\begin{array}{l}1.497^{* * * *} \\
(0.354)\end{array}$ \\
\hline Only elected nationally & $\begin{array}{l}7.214^{* * * *} \\
(0.376)\end{array}$ & $\begin{array}{l}7.521^{* * * *} \\
(0.376)\end{array}$ & $\begin{array}{l}4.640^{* * * *} \\
(0.605)\end{array}$ & $\begin{array}{l}4.685^{* * * *} \\
(0.250)\end{array}$ & $\begin{array}{l}6.505^{* * *} \\
(0.770)\end{array}$ & $\begin{array}{l}6.603^{* * * *} \\
(0.782)\end{array}$ \\
\hline Elected both levels & $\begin{array}{l}8.271^{* * * *} \\
(0.415)\end{array}$ & $\begin{array}{l}8.269^{* * *} \\
(0.415)\end{array}$ & $\begin{array}{c}3.951^{* * * *} \\
(0.484)\end{array}$ & $\begin{array}{l}3.970^{* * *} \\
(0.488)\end{array}$ & $\begin{array}{l}7.780^{* * *} \\
(1.043)\end{array}$ & $\begin{array}{l}7.810^{* * *} \\
(1.045)\end{array}$ \\
\hline Party ID & & $\begin{array}{c}0.006 \\
(0.203)\end{array}$ & & $\begin{array}{c}0.773 \\
(0.516)\end{array}$ & & $\begin{array}{l}-0.251 \\
(0.868)\end{array}$ \\
\hline Information & & $\begin{array}{c}0.366 \\
(0.524)\end{array}$ & & $\begin{array}{l}1.578^{* * *} \\
(0.578)\end{array}$ & & $\begin{array}{l}-0.562 \\
(0.675)\end{array}$ \\
\hline Constant & $\begin{array}{c}-3.613^{* * *} \\
(0.167)\end{array}$ & $\begin{array}{c}-3.845^{* * *} \\
(0.368)\end{array}$ & $\begin{array}{c}-1.154^{* * * *} \\
(0.149)\end{array}$ & $\begin{array}{c}-2.146^{* * * *} \\
(0.383)\end{array}$ & $\begin{array}{c}-2.743^{* * * *} \\
(0.286)\end{array}$ & $\begin{array}{c}-2.402^{* * * *} \\
(0.481)\end{array}$ \\
\hline $\begin{array}{l}N \\
\text { pseudo } R^{2}\end{array}$ & $\begin{array}{l}3172 \\
79.14\end{array}$ & $\begin{array}{l}3172 \\
79.16\end{array}$ & $\begin{array}{c}551 \\
36.29\end{array}$ & $\begin{array}{c}551 \\
37.78\end{array}$ & $\begin{array}{c}559 \\
66.47\end{array}$ & $\begin{array}{c}559 \\
66.57\end{array}$ \\
\hline $\begin{array}{l}\text { Percentage correctly } \\
\text { predicted }\end{array}$ & 96.44 & 96.44 & 80.58 & 80.76 & 92.15 & 92.15 \\
\hline
\end{tabular}

Note: entries are results of logistic regression models explaining whether or not the voter thinks the party she voted for won the election. Election-dummies are included in the models, but not reported for space considerations. Significance levels: ${ }^{*}: \mathrm{p}<0.05 ;{ }^{* *}: \mathrm{p}<0.01 ;{ }^{* * *}: \mathrm{p}<0.001$

The results presented in Table 8 suggest that voters whose party was elected in their district but not at the national level are significantly more likely to believe this party won the election than voters whose party was not elected on any level. Furthermore, as was clear in Table 7 , those voters whose party was elected at the national level only or at both levels are even more likely to feel like their party won the election - and additional analyses show that the difference between these two latter groups is not significant. These results are robust against controlling for party identification and political information. Hence, the results strongly suggest that having one's candidate elected in the district to some extent attenuates the effect of having one's party in opposition at a higher level.

\section{Conclusion}

There is a large literature analysing the impact of winning or losing elections on voter's attitudes as satisfaction with democracy and political trust. However, these studies pay little attention to voters' individual perceptions of whether the party they voted for won or lost the election. This study fills this gap by investigating voters' own perceptions of whether winning 
and losing. Using the MEDW data sets, we set out to determine which aspects of electoral outcomes shape voters' subjective perceptions in Canada, Spain, and Germany.

The analyses show that whether one's party was the largest party in the election or not best explains peoples' feelings of victory or defeat. Hence, voters seem to understand 'winning' first and foremost in majoritarian terms. However, next to this indicator we also find significant effects of alternative indicators that are more in line with consensual views on democracy. In Canada, change in seat shares seems to matter for voters' perceptions as well, although the effect is substantively small. In Spain, then, both the change in seat share as well as the gains or losses in votes affect voters' perceptions. Finally, in Germany, change in vote share helps explaining voters' feelings of winning and losing. However, while alternative measures of 'winning' and 'losing' do matter, our main conclusion is clear and simple: Most voters, like most political scientists, construe winning or losing an election to mean, first and foremost, that the party is the largest party in the election.

Taking into account this measure of winning and losing, we went on to examine whether voters care mostly about winning their district or the national government. Interestingly, while those who voted for the party that enters government but that is not elected in their district do not significantly differ in their perception of winning and losing compared to voters whose party was successful at both levels, voters whose party is in the opposition at the national level but whose candidate was elected in their district are significantly more inclined to think that their party is a winner than voters whose parties were unsuccessful at both levels. Hence, even though previous research has found that electoral outcomes at the district level do not significantly affect voters' level of satisfaction with democracy, they seem important for some voters in terms of whether they view their party as a winner. Future research could isolate the characteristics of those voters who attribute more importance to the district outcome.

Although the study results in clear conclusions, some limits of the analyses should be taken into account as well. In our analyses, we rely on data from Canada, Spain, and Germany only. Although the three cases under investigation represent different electoral systems, it can be reasonably assumed that the results would differ across contexts. In highly fragmentised party systems with government coalitions formed of multiple parties, for instance, it might be very difficult for voters to ascertain the performance of the parties in the election. On the other hand, in a case like Switzerland - in which all major parties are by definition part of the government coalition - winning and losing can be expected to be about something else than being in government. Furthermore, all countries under investigation have a stable party system with a limited number of party blocs - and it thus should not come as a surprise that being in 
government or not strongly affects voters' perceptions of winning and losing. Hence, the results should only be interpreted in the context of the countries under investigation. Moreover, none of the elections covered by our study produced 'ambiguous' outcomes, whereby the party with most votes does not have a plurality of seats and/or does not enter government. Future research should examine more specifically such ambiguous cases. Finally, it would be interesting to take into account voters' expectations before the election. Do voters feel like winners (losers) when their party performed better (worse) than expected? Unfortunately, our data do not include measures of voters' expectations, and we are therefore unable to address this question. We leave it for future research.

Despite these limitations, and with the data at hand, the main conclusion of the study is that the basic assumption of previous research on the winner/loser-gap seems to be confirmed. Winning is first and foremost about being the largest party. 


\section{References}

Anderson, C. J., Blais, A., Bowler, S., Donovan, T., \& Listhaug, O. (2005). Losers' Consent: Elections and Democratic Legitimacy. Oxford: Oxford University Press.

Anderson, C. J., \& LoTempio, A. J. (2002). Winning, Losing and Political Trust in America. British Journal of Political Science, 32(2), 335-351.

Blais, A. (2010). "Making Electoral Democracy Work.” Electoral studies 29: 169-170.

Blais, A. \& Bodet, M. A. (2006). How Do Voters Form Expectations About the Parties' Chances of Winning the Election? Social Science Quarterly, 87(3), 477-493.

Blais, A. \& Gélineau, F. (2007). Winning, Losing and Satisfaction with Democracy. Political Studies, 55(2), 425-441.

Blais, A., Morin-Chassé, A., \& Singh, S. P. (2017). Election Outcomes, Legislative Representation, and Satisfaction with Democracy. Party Politics, 23(2), 85-95.

Campbell, A., Converse, P., Miller, W. E., \& Stokes, D. (1960). The American Voter. New York: Wiley.

Esaiasson, P. (2011). Electoral Losers Revisited - How Citizens React to Defeat at the Ballot Box. Electoral Studies, 30(1), 102-113.

Ferland, B. (2015). A Rational or a Virtuous Citizenry? - the Asymmetric Impact of Biases in Votes-Seats Translation on Citizens' Satisfaction with Democracy. Electoral Studies, 40(1), 394-408.

Henderson, A. (2008) Satisfaction with Democracy: The Impact of Winning and Losing in Westminster Systems. Journal of Elections, Public Opinion and Parties, 18(1), 3-26.

Hooghe, M. \& Stiers, D. (2016). Elections as a Democratic Linkage Mechanism: How Elections Boost Political Trust in a Proportional System. Electoral Studies, 44, 4655.

Kostelka, F. \& Blais, A. (2018). The Chicken and Egg Question: Satisfaction with Democracy and Voter Turnout. PS: Political Science \& Politics, 52(1), 370-376.

Kselman, D. \& Niou, E. (2011). Protest Voting in Plurality Elections: A Theory of Voter Signalling. Public Choice, 148(3-4), 395-418.

Lijphart, A. (2012). Patterns of Democracy (2 $2^{\text {nd }}$ ed.). New Haven: Yale University Press.

Powell, B. G. (2000). Elections as Instruments of Democracy: Majoritarian and Proportional Visions. New Haven: Yale University Press.

Stephenson, Laura, André blais, Damien Bol and Filip Kostelka (2017). Making Electoral Demcracy Work. Harvard Dataverse, V1. 
Singh, S., Karakoç, E., \& Blais, A. (2012). Differentiating Winners: How Elections Affect Satisfaction with Democracy. Electoral Studies, 31(1), 201-211.

Singh, S. P., Lago, I., \& Blais, A. (2011). Winning and Competitiveness as Determinants of Political Support. Social Science Quarterly 92(3), 695-709.

Stiers, D. \& Dassonneville, R. (2018). Affect Versus Cognition: Wishful Thinking on Election Day. An Analysis Using Exit Poll Data from Belgium. International Journal of Forecasting, 34(2), 199-215.

Thomassen, J. (2000). Representation and Accountability. In: J. Thomassen (ed.). Elections and Democracy. Representation and Accountability. (pp. 1-19). Oxford: Oxford University Press. 